The University of San Francisco

USF Scholarship: a digital repository @ Gleeson Library |

Geschke Center

2014

\title{
Using Common-Pool Resource Principles to Design Local Government Fiscal Sustainability
}

Shui-Yan Tang

Richard Callahan

University of San Francisco, rfcallahan@usfca.edu

Mark Pisano

Follow this and additional works at: http://repository.usfca.edu/pna

Part of the Business Commons

\section{Recommended Citation}

Shui-Yan Tang, Richard F Callahan, Mark Pisano. Using Common-Pool Resource Principles to Design Local Government Fiscal Sustainability. Public Administration Review. Volume 74, Issue 6, pages 791-803, November/December 2014.

This Article is brought to you for free and open access by the School of Management at USF Scholarship: a digital repository @ Gleeson Library | Geschke Center. It has been accepted for inclusion in Public and Nonprofit Administration by an authorized administrator of USF Scholarship: a digital repository@Gleeson Library | Geschke Center. For more information, please contact repository@usfca.edu. 


\section{Using Common-Pool Resource Principles to Design Local Government Fiscal Sustainability}

This article analyzes local government fiscal sustainability as a common-pool resource (CPR) problem. Comparing the experiences of Los Angeles County, San Bernardino City, and San Bernardino County, California, the analysis applies a framework developed from three decades of CPR research to show the importance of six micro-situational variables—communications with the full set of participants, known reputations of participants, high marginal per capita return, entry or exit capabilities, longer time horizon, and agreed-upon sanctioning capabilities -in shaping collective action dynamics and building the trust and reciprocity among stakeholders needed to achieve fiscal sustainability. The underlying contextual conditions for these micro-situational variables vary based on specific socioeconomic and political settings, but the findings suggest that institutions and processes can be designed based on several well-tested principles in CPR governance to encourage stakeholders to look beyond their immediate self-interests and make decisions that account for the community's long-term fiscal sustainability.

$\mathrm{F}$ iscal sustainability has become and will continue to be a major challenge for local governments in the United States. As forecast by the U.S. Government Accountability Office (2013), operating deficits for state and local governments will increase and continue for decades. Reduced tax revenues resulting from demographic changes will also create budgetary stresses for governments at all levels, and these stresses will continue for decades (Pisano 2013b). Confronting these fiscal sustainability challenges requires coordinated efforts among multiple actors in the local community, both inside and outside government, to
Many fiscal challenges currently facing state and local jurisdictions in the United States resemble the classic tragedy of the commons. trend continues, many more cities around the country may face the prospect of chronic fiscal imbalance and, perhaps, bankruptcy in the future. In the current public finance and budgeting literature, many quantitative studies link various institutional, political, and socioeconomic variables to local fiscal decisions, mostly based on cross-sectional data at a given point in time; yet few qualitative studies provide detailed and over-time analyses of the processes and mechanisms by which local stakeholders may gradually overcome collective action problems to develop fiscal sustainability.

In this article, we analyze local government fiscal sustainability as a common-pool resource (CPR) problem. Originally developed to examine natural resource governance issues, the CPR perspective is well suited to studying public sector fiscal sustainability issues because they share similar collective action problems (Feiock and Scholz 2010). A long tradition of academic research on CPRs has adopted a case study approach (Ostrom 1990). Similarly, we draw on our three-year, in-depth case study research and apply the framework from findings in the CPR literature to explain the results of in-depth case studies of three local jurisdictions-Los Angeles County, San Bernardino City, and San Bernardino County-conducted between 2011 and 2013.

Many fiscal challenges currently facing state and local jurisdictions in the United States resemble the classic tragedy of the commons, a situation in which most users understand that the existing way of using the CPR will eventually lead to its ruin, but no one is willing to refashion institutions, budgetary processes, and core assumptions about ways for funding and delivering local public services. As evidenced by a number of highly visible municipal bankruptcy cases in the recent past, including the cities of Detroit, Michigan, and San Bernardino, California, if this reduce one's use or contribute to its replenishment if no credible means exists to overcome the inherent collective action problems. CPRs have two basic characteristics: difficulty of excluding potential beneficiaries and subtractability of use (Ostrom 2005). Because of
Shui-Yan Tang is Frances R. and John Duggan Professor in Public Administration in the Sol Price School of Public Policy and research director for the Judith and John Bedrosian Center on Governance and the Public Enterprise, University of Southern California.

E-mail: stang@usc.edu

Richard F. Callahan chairs the Department of Public and Nonprofit Administration in the University of San Francisco's School of Management. E-mail: rfcallahan@usfca.edu

Mark Pisano is Professor of the Practice of Public Administration in the Price School of Public Policy, University of Southern California, and co-chair of the Federal System Panel of the National Academy of Public Administration.

E-mail: mpisano@usc.edu
Public Administration Review, Vol. 74, Iss. 6, pp. 791-803. (@ 2014 by The American Society for Public Administration. DOI: 10.1111/puar.12273. 
these two basic characteristics, many CPRs are susceptible to collective action problems in relation to provision and appropriation. Provision problems relate to the types of efforts needed to maintain a resource's long-term productive (i.e., supply) capacity; appropriation problems relate to collective efforts needed to limit appropriation of (i.e., demand for) resource units in order to maintain the resource system's sustainable yield in the long run.

Public sector fiscal decisions resemble CPR problems. As suggested by Von Hagen, "At the heart of the common-pool problem of public finances is an externality that results from using general tax funds to finance targeted public policies" $(2006,470)$. In other words, government revenues are pooled together from diverse sources; the costs of public expenditures are generally paid for by the entire political jurisdiction, while the benefits of specific government expenditures tend to be concentrated among specific groups (Baqir 2002; Weingast, Shepsle, and Johnsen 1981). Thus, each group (and its political representatives) wants to get a larger share of the common revenue pool. Those who benefit from each specific program prefer a budgetary allocation that is higher than the socially optimal level. But if every group tries to maximize its share, the collective outcome will be excessive public spending, unsustainable deficits, or fiscal crisis.

A balanced and sustainable budget benefits everyone in the community. If the existing institutions and processes for allocating fiscal resources for different purposes can no longer provide for a sustainable and economically sound budget, no one wants to accept cutbacks unilaterally. Everyone, however, is potentially worse off if the political jurisdiction faces long-term budgetary shortfalls, bankruptcy, or other major operational disruptions. The collective action problems that participants face in their efforts to restructure the institutions and processes for fiscal decision making constitute a second-order prisoner's dilemma. Collective action problems are especially serious during major economic downturns; as funds become increasingly scarce, stakeholders are more motivated to fight to preserve their own share of the budget, disregarding the impact on the jurisdiction's long-term fiscal health. The classic tragedy of the commons occurs when short-term imperatives-for example, resolving collective bargaining through the deferral of costs-deplete available resources in the long term. Nonetheless, the tragedy of the commons is not necessarily immutable if stakeholders believe that there are credible means of increasing revenue sources or of sharing the pains of budgetary cuts equitably and that they will be better off in the long run by supporting short-term belt-tightening and altering their operational strategies. Drawing on the comparison of three case studies, this article shows how theoretical postulates derived from the CPR research regarding interactive dynamics and institutional design principles help explain the success or failure of local governments in addressing fiscal commons dilemmas.

To set the stage for our three-case comparison, we provide an overview of the extant literature on the political economy of fiscal institutions, followed by an initial discussion of the analytical leverage provided by approaching fiscal challenges as CPR problems. This is followed by an analysis of the case of Los Angeles County, mostly in terms of how the case aligns with the findings in the CPR literature.
We then analyze the case of San Bernardino City, which declared bankruptcy in 2012. The third case is San Bernardino County, which illustrates possible ways of averting a fiscal crisis through concerted efforts by the key stakeholders. The next section links the cases to well-established theories about the interactive dynamics and institutional design variables that characterize sustainable CPR governance. The final section draws conclusions about the utility of the CPR framework for studying and facilitating fiscal sustainability.

\section{Fiscal Institutional Factors}

In an overview of the extant literature on the political economy of fiscal institutions, Von Hagen (2006) identifies three general types of institutional arrangements - ex ante fiscal rules, electoral rules, and the budgetary process - that can potentially address the CPR problems inherent in public finance and budgeting. First, ex ante fiscal rules - such as balanced budget requirements, numerical debt ceilings, and preset limits on the growth of taxation and spending - can limit the growth of public expenditure. A common drawback of such rules, however, is that decision makers can often circumvent them and, in the process, produce unintended negative consequences. For example, balanced budget requirements may create incentives for decision makers to look at the short term while neglecting the long-term problems created by short-term fixes, such as delayed maintenance on critical infrastructures, shifting financial obligations to future generations, and others (Bifulco et al. 2012).

Second, electoral rules shape elected officials' preferences for fiscal allocation. As shown by Baqir (2002), for example, after controlling for other possible determinates, U.S. municipal governments with larger numbers of legislators tend to have higher public spending per capita because individual legislators are motivated to make spending proposals that benefit their own constituencies. Such an effect is mitigated in cities that have a strong-mayor form of government, but the effect is not affected by whether the legislators are elected at-large or from individual districts. The results, however, leave open the question as to whether some communities may have adopted a strong-mayor form of government as a way to control public spending in the first place.

Third, the budgetary process matters. For example, it is often posited that a more centralized budgetary process, coupled with transparency, encourages all participants to resolve their competing claims on the budget in a coordinated manner (Peterson 1995). Yet how the budgetary process can be centralized and made more transparent is contingent on the underlying institutional structures. For example, in a strong-mayor form of municipal government, the mayor's office can be the focal point for negotiating and implementing budgetary deals. In municipal governments in which the heads of major departments are independently elected, different forums and mechanisms for budget negotiation and implementation may be needed.

\section{A Collective Action Perspective}

These three types of fiscal design are important, yet by themselves they do not fully explain why some communities are more successful than others in confronting major fiscal challenges. First of all, different factors work together in a configurative way; for example, different combinations of ex ante fiscal rules and electoral rules 
may favor different types of budgetary processes. A related question concerns the possible endogeneity of institutions - that is, on the one hand, fiscal and electoral rules condition the budgetary process, while on the other hand, different fiscal and electoral rules may themselves be results of efforts to improve the budgetary process. In addition, to be viable tools, institutional arrangements must be self-enforcing in the long run, that is, participants must have self-motivated reasons to abide by them if they expect other participants to do the same (Greif 2006; Knight and Johnson 2011; Tang 2012). What conditions are conducive to the establishment and maintenance of institutions for ensuring fiscal sustainability in local governments?

Ideas for tackling these difficult issues can be found in the broader literature on CPR governance. Ostrom (2005) argues that CPR problems cannot be effectively resolved by cookie-cutter methods or by simply drawing on the traditional research methods focused on the study of either "the state" or "the market." In many circumstances, locally developed solutions that are neither state nor market driven are better suited to the underlying ecological, socioeconomic, and governance contexts, suggesting the need for institutional diversity in addressing varied CPR situations. Yet one cannot go to the extreme by claiming that each situation is unique and requires an entirely different solution; if so, no systematic scholarly work on the subject would be possible. CPR research, as with public administration research, has been advanced through interdisciplinary frameworks (Raadschelders 2011). Specifically, one needs to (1) understand the typical situations participants find themselves in relation to CPR problems, (2) analyze the "micro-situational" conditions that are conducive to participants resolving their CPR problems, and (3) develop general frameworks (or models) that can identify major factors and how these factors may combine to affect the ways participants interact with one another in different CPR situations.

As argued by Ostrom $(1990,2010)$, for users to successfully manage a CPR in the long run, they need to develop trust and reciprocal relationships with each other, learning how to work together to develop and enforce an appropriate set of rules that will help them overcome various types of commons dilemmas related to provision and appropriation issues. Extensive experimental research has been conducted in the past three decades to examine the microsituational conditions under which participants in social dilemma settings are likely to cooperate with each other to produce mutually beneficial outcomes. As summarized by Ostrom (2010, 661-62), these findings include the following:

- Communication is feasible with the full set of participants

- Reputations of participants are known

- High marginal per capita return for participants in successful collective efforts

- Entry or exit capabilities for key participants so that no one will be taken for granted

- Longer time horizon

- Agreed-upon sanctioning capabilities

Because these results were derived from experimental research, for them to be useful as policy and management tools, they need to be mapped onto specific contextual attributes-specific features of the resource system, resource units, users, and governance system. Based on more than three decades of in-depth field research on a variety of CPRs-irrigation systems, groundwater basins, fisheries, forests, and others-Ostrom and associates identify a number of contextual variables related to the resource system, resource units, governance system, and users that are most likely to impact CPR users' chances of overcoming resource use dilemmas (Blomquist, Schlager, and Heikkila 2004; Lam 1998; Ostrom 1990; Ostrom, Gardner, and Walker 1994; Schlager and Heikkila 2011; Tang and Tang 2001; Tang 1991, 1992), with additional research applying the CPR framework to regional and federal governance (Callahan 2007; Feiock 2013; Feiock and Scholz 2010).

As argued by Ostrom (2005), no definite sets of operational and collective choice rules can be the magic bullet for resolving CPR problems in all circumstances. Rather, it is by careful experimentation that CPR users can work together to develop a governance system that fits the resource system, resource units, and users of their specific CPR. In this respect, eight institutional design principles, as originally presented in Ostrom (1990) and further refined later in Ostrom (2005), have remained a useful guide for linking the six micro-situational variables to the contextual variables that explain successful CPR governance. The eight principles are (1) clearly defined boundaries, (2) proportional equivalence between benefits and costs, (3) collective choice arrangements, (4) monitoring, (5) graduated sanctions, (6) conflict-resolution mechanisms, (7) minimal recognition of rights to organize, and (8) nested enterprises. ${ }^{1}$

This list of principles goes beyond the fiscal rules, electoral rules, and budgetary processes that were identified as critical institutional factors affecting financial CPR problems. Instead, the list highlights the importance of institutional arrangements, both formal and informal, that take into account the interactive dynamics among the resource system, resource units, and users of a CPR.

These principles are not blueprints but can be seen as "structural similarities" among robust, long-serving CPR systems (Ostrom $2005,257)$. They can also be viewed as guidelines for designing institutions that support the six micro-situational processes conducive to the resolution of CPR problems. Although these eight principles have been shown repeatedly to be useful guidelines for designing robust institutions for CPRs in the natural world, a key question is how many of them may be directly relevant for other types of CPRs, as in the case of the fiscal commons, which involves not only collective action problems parallel to those prevalent in natural CPRs but also some of its own unique problems. Understanding the applicability of these principles will add to the current public finance literature; it may also help us resolve the puzzle regarding the endogenous and configurative effects of institutional variables on public financial decisions.

In this article, we apply Ostrom's insights into micro-situational variables and institutional design principles for robust CPR governance to examine what accounts for the divergent fiscal performance of three local jurisdictions in California: Los Angeles County, San Bernardino City, and San Bernardino County. Developing in-depth case studies to address complex problems allowed Ostrom's CPR research to "examine the factors that appeared to account for the robustness of some systems and the failures of others" (Ostrom 2006 , 5). Similarly, the case study research design in this project 
facilitates an in-depth comparison of jurisdictions successfully sustaining their fiscal commons with a jurisdiction that filed for bankruptcy. This research design addresses the "how" question of explaining how differences emerge, which is a particular strength of case study research (Yin 1994). Additionally, case study research design addresses the nuanced questions of governance (Heinrich, Hill, and Lynn 2004).

The case studies were conducted mainly through interviews with key stakeholders between 2011 and 2013. More than 10 interviews were conducted in each city. Most of the interviews lasted more than one hour, and the interviewees were ensured anonymity. For most interviews, we used a set of questions that we prepared ahead of time to ensure that we covered all the main issues we wanted to learn from the interviewee. Additional questions were raised during the interview based on the interviewee's initial responses to the prepared questions. Interviewees in each case included key elected officials (including board, council, and committee members and chairs), chief administrative officers, department heads, staffs of elected offfcials, leaders of charter revision commissions, labor leaders, and business and community leaders. We also consulted secondary sources, including newspaper reports, documents from bond rating agencies, official Web sites, and official planning and budgeting documents. Expert panels of researchers and experienced practitioners in local government reviewed the case studies over a three-year period to check for accuracy and to comment on the case descriptions.

As the details for each case study have already been published (Callahan and Pisano 2014; Pisano and Callahan 2012, 2013a), this article provides only a brief sketch of each and instead focuses on comparing lessons from the cases. Two levels of analysis—one at the micro-situational level and the other at the institutional design levelare used in our comparison.

At the micro-situational level, we focus on the interactive dynamics among key fiscal stakeholders in the local jurisdictions; specifically, we use Ostrom's six micro-situational conditions identified in experimental settings to examine how stakeholders and leaders in the three jurisdictions differ in how they interact with each other in fiscal decision processes. Differences in these micro-situational dynamics help us make sense of how varying dynamics contribute to different fiscal behaviors and outcomes. Different from the aggregate measurements used in quantitative studies on similar topics, information that we gathered from in-depth interviews with stakeholders in each case allows us to lay out in greater detail the underlying mechanisms of these situational dynamics.

Next, we draw on Ostrom's questions regarding the practical application of her eight design principles for sustainable CPR governance and use them as a template for relaying micro-situational dynamics to institutional design issues. As will be shown in the subsequent discussion in this article, these principles do not point to any specific set of political structures as a prerequisite for fiscal sustainability, but they do highlight crucial institutional variables, both formal and informal, that are important for sustaining the local fiscal commons.

In the rest of this article, we first briefly outline each case. Then we examine how the three cases match or mismatch each of Ostrom's six micro-situational variables. Next we summarize lessons from the three cases by examining them in the context of eight questions on institutional design principles.

\section{The Exemplary Practices of Los Angeles County}

With a population of close to 10 million, Los Angeles County is the largest county in the United States. The county is highly diverse, with minorities accounting for more than 50 percent of the population. With more than 100,000 employees, the county government provides direct municipal services to almost a million people who live in the unincorporated area (outside the 88 incorporated cities in the county), in addition to providing the usual county-level services such as public assistance, public safety, health and human services, and transportation.

Like other counties in California, Los Angeles County's revenuegenerating power is highly constrained, especially since passage of Proposition 13 in the 1980s, which has severely limited the ability of local jurisdictions to raise revenues through tax increases without two-thirds voter approval. Since Proposition 13, larger amounts of local revenues have been redirected through the state. The overall fiscal situation in Los Angeles County in the past three decades has been one of reduced discretion coupled with constrained revenues and increasing service needs. Despite this challenging environment, Los Angeles County has been relatively successful in maintaining fiscal sustainability. In the face of the recent economic downturn, the county has managed to maintain the following bond ratings: Moody's MIG 1, Standard \& Poor's SP 1+, and Fitch's F1+.

Several contextual and incidental factors—structural features, critical events, the budgetary process, and labor relations_-are relevant for understanding why Los Angeles has been able to maintain fiscal sustainability.

\section{Structural Features}

The county is governed by a board of five supervisors, who traditionally had long tenure, with many of them serving continuously for decades. Term limits of three consecutive four-year terms were approved by voters in 2002. Because the provision was not retroactive, several long-serving supervisors are still in the board, with their terms scheduled to expire in the next few years. The long tenure of the county supervisors encouraged the board members to adopt a relatively conservative approach to budgeting, as they realized the likelihood of facing the negative consequences created by current fiscal mistakes many years later. In Los Angeles County, the supervisors are highly involved in the budgetary process, and this helps translate their more conservative approach to fiscal matters into actual practices.

In the past two decades, the board of supervisors has gradually given the chief administrative officer more power. Traditionally, the county government had a stovepiped and fragmented administrative structure, with each supervisor overseeing a range of departments, thus making it difficult for departments to coordinate with each other. Such a fragmented structure was gradually reintegrated by the strong leadership of a succession of well-respected chief administrative officers since the 1980s continuing to today. In 2007, the board changed the administrative system from a chief administrative officer (CAO) model to a chief executive officer (CEO) model. In the current CEO 
model, the CEO selects the department heads (with approval by the board), who report to the CEO for budgeting and coordination except for those elected countywide, such as the sheriff.

\section{Critical Events}

The path to fiscal sustainability in Los Angeles has involved several critical events. The first event occurred during the national recession of 1988-92. During that period, Orange County declared bankruptcy, and Los Angeles County was under close scrutiny by its lenders. Credit Suisse, a major lender to the county, requested a conference call during a regular board meeting on a Tuesday morning. The supervisors felt compelled to adjourn the board meeting and took the call. This event helped strengthen the supervisors' resolve for greater fiscal discipline. During the early 1990s, however, the supervisors had yet to turn their resolve into actual discipline because they lacked the organizational culture, administrative structure, and communication processes to carry it out.

In 1997, CAO David Janssen, who had taken office the previous year, inherited an $\$ 800$ million budget deficit and was presented with four competing budget proposals from the supervisors. To deal with the situation, Janssen introduced a more disciplined budgetary process and successfully negotiated a renewal of billions of dollars of federal waivers for the county hospital system. Janssen's actions led to sustained budget balances in the following decade. Upon Janssen's retirement in 2007, Bill Fujioka took over as the new CEO with enhanced powers. The county faced budget shortfalls during the recession of 2008-09 but was able to implement new measures in supply chain management, achieve budget reductions without layoffs, and maintain the county's credit ratings.

\section{Budgetary Process}

With the support of the board of supervisors, Janssen gradually developed a budgetary process based on procedures to ensure transparency, consistent information flows across departments, and integration through a single point of coordination, with presentation of all relevant information and options for the supervisors' consideration and avoidance of creating sensational political issues through freewheeling leaks to the press. Gradually, these open and transparent procedures helped create and sustain an organizational culture that supported the principles of (1) need-based instead of allocation-based budgeting; (2) conservative practices that included counting budget revenues that are agreed upon and that will continue beyond the current year, while excluding one-time funds that force ongoing or open-ended commitments in the operating budget; and (3) linking performance and efficiency evaluation to the budgetary process.

These budgetary principles were further reinforced by (1) longserving supervisors being fluent in fiscal matters and highly engaged with the $\mathrm{CAO} / \mathrm{CEO}$ in the budgetary process, (2) strategic planning processes involving coordinated participation from departments, (3) transparent and orderly flows of information from a staff with highly developed professional skills in budgeting, and (4) the board and staff working closely to confront various fiscal crises.

\section{Labor Relations}

Over the past three decades, the county was able to negotiate with the unions to adjust the pension system, which is now a six-tier pension program with reduced benefits for newer hires. In the 1990s, the county, following the budgetary principles identified earlier, was able to resist the political pressure prevalent in California at the time to adopt new benefits packages for all public employees, including the provision for calculating pension benefits based on 3 percent of salary per year served with retirement at age 55 , which in recent years has turned out to be a major source of financial headache for many other government jurisdictions in California. The county administration has built a level of trust with the unions by virtue of its ability to maintain a fiscally sound budget and pension system and to make salary and benefit adjustments that are appropriate for the economic conditions overtime.

\section{The Bankruptcy of San Bernardino City}

With a population of approximately 200,000, San Bernardino City is the seventeenth-largest city in California. In fiscal year 2012, the city reported a $\$ 45$ million deficit on a projected budget of $\$ 65$ million, with reserves depleted (Shanforth and Lawson 2013). With a projected debt of $\$ 240$ million (including $\$ 47$ million in pension obligations) and continuing deficits in the coming years, the city council declared bankruptcy under chapter 9 in July 2012. It was the largest municipal bankruptcy in the United States at the time, before Detroit took the title in 2013.

The filing contrasted dramatically with the All-America City Award it received from the National Civic League in 1978. For several decades before the 1980s, San Bernardino was one of the fastest-growing areas in the region. Beginning in the late 1970s, however, the city began to lose jobs, as several major employers, including Kaiser Health Care System and Norton Air Force Base, closed. The city's economy also suffered as a result of the regional development pattern, which shifted commercial and entertainment activities to the nearby cities of Ontario and Rancho Cucamonga, about 15 miles west of San Bernardino City. The housing market collapse since the Great Recession further undermined the local economy by eliminating many residential construction jobs. More than 70 percent of city residents are renters, with the majority of the property owners residing outside the city.

\section{Structural Features}

Established as a charter city in 1906, San Bernardino has a sevenmember council elected by district. The mayor, attorney, clerk, and treasurer are elected. Elected citywide, the mayor has extensive powers, with the majority of the staff reporting to him or her. Although the mayor sits on the council, he or she does not have a vote. The mayor has veto power over council decisions, but vetoes can be overridden by a supermajority vote of the council. In the past four decades, there has been a succession of several relatively long-serving mayors. The mayor and council members are subject to term limits.

As the only elected official not subject to term limits, the city attorney has played a central role in policy making and operations, as the city charter accords the city attorney the exclusive authority to interpret the charter. The previous city attorney had served six terms since 1987 and was only recently defeated for reelection in November 2013. The city attorney's involvement in policy and operational issues has created considerable conflicts between the office of the mayor and that of the city attorney. The conflicts became so intense that a past mayor requested and obtained a 
restraining order on the city attorney. A city administrator traditionally headed the administrative system. The system was changed to a city manager form in 2006, with enhanced powers to oversee city department heads.

The city has used the charter to set operational and budgetary policies. Section 186 of the charter ties salary increases for police officers and firefighters to the average increase in public safety units in 10 specific California cities, most of which are located in the more prosperous Orange County and the San Francisco Bay area. The result has been automatic increases that have outpaced the city's fiscal capacity.

\section{Critical Events}

In addition to charter provisions for automatic salary adjustments, the city council approved in 2004 a pension program for public safety personnel, in which pension payments are based on 3 percent for each year of service with retirement eligible from the age of 50 . In addition, health coverage continues until the retiree becomes eligible for Medicare. At the time of the bankruptcy filing, the state pension system, CalPERS (California Public Employees' Retirement System), was listed as the "largest single creditor at more than $\$ 140$ million," with the CalPERS legal filing asserting that "the city was trying to improperly renege on its pension debts" (Walters 2012).

Several years before filing for bankruptcy, the city council did try to improve the city's operational and financial management by changing the city administrator position to a city manger position, giving the latter position more enhanced authority over city departments. Experienced professionals were brought in to fill the city manager position. Nationally known facilitators were brought in to help organize policy retreats to consider strategies to revamp the city's cost structure. These efforts provided some momentum for change but subsequently gave way to the prevailing city politics (which will be further explained below). In 2012, the city's financial plight was compounded when the state governor and legislature eliminated redevelopment agencies throughout the state, resulting in the use of operating revenues to offset staff costs.

\section{Budgetary Process}

The exchange between the city attorney and the mayor in the July 2012 council meeting - accusing each other of not knowing the city's true fiscal condition - was symptomatic of a lack of collaboration among the city's key institutional actors in the budgetary process. A lack of collaboration, together with charter provisions guaranteeing highly generous pay raises and pension benefits to public safety officers, has made it difficult for the city to adjust its financial choices in response to changing economic situations and state polices. Although the mayor and city manager attempted to introduce a more coordinated approach to budgeting, their efforts failed to turn the situation around.

\section{Labor Relations}

The public safety unions for police and fire are well organized. Less than 10 percent of the 100-plus uniformed members live inside the city. The public safety unions are politically active, and they are known to be effective in handing electoral defeat to council members who advocated for change in pension policy. The unions advocated for increasing compensation adjustments and strengthening the authority of the city attorney in charter amendments. Nonetheless, there were no other organized efforts by other civic groups that could moderate these efforts. Many of the active civic groups that helped the city earn the All-America City Award back in 1978 are no longer active.

\section{Averting Financial Crises in San Bernardino County}

In terms of government structures and functions, San Bernardino County is similar to Los Angeles County. With a population of more than 2 million, San Bernardino County has a five-member board of supervisors elected by district. In addition to making legislative decisions, the supervisors possess executive powers in hiring and firing senior administrative staff and overseeing county departments. Historically, supervisors were eager to protect the financial interests of their respective districts, with few incentives for engaging in priority setting across districts. Similar to Los Angeles County, San Bernardino is vulnerable to state transfers and funding. As cities in the region faced economic downturns, San Bernardino County had to face extra financial burdens in taking up the slack in public safety, redevelopment, and other services.

Being in the same region, San Bernardino County experienced similar economic pressures faced by San Bernardino City-reductions in property tax and sales tax revenues, increased unemployment, and residents leaving because of unaffordable mortgages. In addition to external economic forces, many political problems have historically plagued the county government. The local and regional press regularly ran articles featuring the cumbersome administrative structure and inefficient operations of the county government. The county was also known for its dysfunctional political culture, including corruption charges and convictions of an elected supervisor and staff members for violating state law, as well as large legal judgments against the county awarded to developers.

When the Great Recession hit, the county was in an uncertain financial condition. During the 2009 budget cycle, for example, the county ran an $\$ 80$ million deficit, which was subsequently rolled into the following year. The structural deficit in the county developed from failures to account for the full costs of capital projects and collective bargaining agreements with county employees, county agreements to provide services for other local jurisdictions without charging for the full overhead costs, and a lack of coordination across departments in making budget decisions.

A window of opportunity opened up when two new supervisors were elected in 2008. Chaired by Garry Ovitt, former mayor of Ontario, California, the new board subsequently hired Greg Devereaux, who had been the city manager of Ontario, as chief executive officer. Devereaux negotiated a five-year employment contract with the board, which gave his office central authority to oversee and coordinate activities across all departments in the county. Instead of reporting directly to each supervisor separately, all department heads now report to Devereaux. This change helped facilitate priority setting across departments and geographic districts in the county. It also allowed the development and implementation of budget priorities and expense reductions to enhance the longterm fiscal health of the county.

The chief executive office developed an integrated finance tracking system across all departments. Each department must include estimates of the full allocation of overhead administrative expenses, 
Table 1 Matching and Mismatching Ostrom's Six Micro-Situational Variables

\begin{tabular}{|c|c|c|c|}
\hline Micro-situational variables & Los Angeles County & San Bernardino City & San Bernardino County \\
\hline $\begin{array}{l}\text { Communication is feasible } \\
\text { with the full set of } \\
\text { participants }\end{array}$ & $\begin{array}{l}\text { Open and structured communications } \\
\text { among elected officials, admin- } \\
\text { istrators, and stakeholders in the } \\
\text { broader community }\end{array}$ & $\begin{array}{l}\text { Few open communications between the city } \\
\text { attorney and mayor/council; the broader } \\
\text { community of stakeholders is seldom } \\
\text { involved in budgetary communications }\end{array}$ & $\begin{array}{l}\text { Efforts to enhance communications across } \\
\text { departments and districts and among stake- } \\
\text { holders in the region }\end{array}$ \\
\hline $\begin{array}{l}\text { Reputations of participants } \\
\text { are known }\end{array}$ & $\begin{array}{l}\text { Good working relationships between } \\
\text { the board and the CEO; trust } \\
\text { between partnering organizations, } \\
\text { including the unions }\end{array}$ & $\begin{array}{l}\text { Key stakeholders (including the city attorney } \\
\text { and public safety unions) are known for } \\
\text { their uncompromising stances in protecting } \\
\text { their vested interests }\end{array}$ & $\begin{array}{l}\text { A new majority in the board, working with a } \\
\text { reputable chief executive, began to demon- } \\
\text { strate a commitment to developing honest } \\
\text { and responsible budgetary decisions }\end{array}$ \\
\hline $\begin{array}{l}\text { High marginal per capita } \\
\text { return for participants } \\
\text { in successful collective } \\
\text { efforts }\end{array}$ & $\begin{array}{l}\text { The budgetary process and person- } \\
\text { nel policy link performance and } \\
\text { efficiencies to budgetary allocations } \\
\text { in different departments }\end{array}$ & $\begin{array}{l}\text { Public safety officers' salaries and benefits } \\
\text { are guaranteed by the charter; they do not } \\
\text { see any high return for working with other } \\
\text { stakeholders }\end{array}$ & $\begin{array}{l}\text { A new budgetary system was put in place } \\
\text { that rewarded departments for sound fiscal } \\
\text { planning and decisions }\end{array}$ \\
\hline $\begin{array}{l}\text { Entry or exit capabilities for } \\
\text { key participants so that } \\
\text { no one will be taken for } \\
\text { granted }\end{array}$ & $\begin{array}{l}\text { Seasoned public management } \\
\text { professionals engage the board on } \\
\text { budgetary issues without fear }\end{array}$ & $\begin{array}{l}\text { Given the deep divisions among elected of- } \\
\text { ficials, executives do not enjoy the security } \\
\text { needed to lead credibly an orderly budget- } \\
\text { ary process }\end{array}$ & $\begin{array}{l}\text { A strong professional reputation and a five- } \\
\text { year employment contract allowed him to } \\
\text { carry out his reform agenda without fear }\end{array}$ \\
\hline Longer time horizon & $\begin{array}{l}\text { Supervisors have long tenure and are } \\
\text { willing to plan for the long term; the } \\
\text { long-term viability of the pension } \\
\text { system encourages employees to ac- } \\
\text { cept compromises in benefit cuts }\end{array}$ & $\begin{array}{l}\text { The city attorney has long tenure, while other } \\
\text { elected officials are subject to term limits; } \\
\text { they have different agendas; the long- } \\
\text { serving city attorney has the public safety } \\
\text { unions as his major source of support }\end{array}$ & $\begin{array}{l}\text { Supervisors are subject to term limits, and } \\
\text { the chief executive officer has a five-year } \\
\text { contract with supermajority protection; a } \\
\text { 10-year expenditure forecast requirement } \\
\text { has been built into the budgetary process }\end{array}$ \\
\hline $\begin{array}{l}\text { Agreed-upon sanctioning } \\
\text { capabilities }\end{array}$ & $\begin{array}{l}\text { Shared commitment to the long term } \\
\text { by all major stakeholders; depart- } \\
\text { ment heads face tangible sanctions } \\
\text { (both formal and informal) for sub- } \\
\text { mitting inflated budgetary requests }\end{array}$ & $\begin{array}{l}\text { Mistrust between elected officials and en- } \\
\text { trenched positions of pubic safety unions } \\
\text { make it difficult for them to reach credible } \\
\text { compromises and enforce them }\end{array}$ & $\begin{array}{l}\text { A more transparent and inclusive budgetary } \\
\text { process has been taking shape; elected of- } \\
\text { ficials and department heads have become } \\
\text { more likely to face sanctions for inflated } \\
\text { budgetary requests }\end{array}$ \\
\hline
\end{tabular}

and budgets presented to the board must include a 10-year expenditure forecast. The $\mathrm{CEO}$ and board created greater transparency and encouraged the identification of cost savings measures across departments and supervisory districts in the county. This also led to more effective uses of federal community development block grant funds based on highest need on a countywide basis, instead of a mechanical split among the supervisorial districts, as had been the case in the past.

The 10-year forecast informed collective bargaining across 16 separate negotiations, leading to agreements to multiple tiers of pension benefits, reduced county matches to pension funds, and reduced annual salary increase increments. Strategic planning processes were convened with the participation of county officials, city officials, civic leaders, and regional planning agency officials to consider (1) long-term strategic allocation of financial and environmental resources for the region and (2) possible ways of leveraging resources from multiple jurisdictions for operating existing resources, such as parks and water resources, for greater cost effectiveness and more sustainable uses. These efforts have enabled the county to continue operations without declaring bankruptcy, but the county is not without continuing fiscal stress. While the county maintains a Moody MIG-1 rating as a whole, its pension obligation bonds have been downgraded.

\section{Linking the Three Cases to the Six Micro-Situational Variables and Questions on Design Principles}

The case of Los Angeles County shows that it takes a long time to build the structural and cultural foundations for overcoming the $\mathrm{CPR}$ problems inherent in fiscal decisions. Once established, such foundations need to be continuously maintained by all key stakeholders in the community-officials, labor, civic organizations, and businesses—-who are willing to support not just their own interests but also the long-term interests of the community. The importance of such "community maintenance" (Gardner 1996) efforts is illustrated by the case of San Bernardino City, which deteriorated from being a National Civic League All-America City in 1978 to declaring bankruptcy in 2012. External economic forces have played a significant role undermining the fiscal condition in San Bernardino City; elected leaders in the city have tried to take steps to avert a financial disaster. Their efforts failed mainly because of their inability to develop a facilitative framework for overcoming the collective action problems inherent in the CPR problems they faced.

San Bernardino County has faced similar challenges as those faced by San Bernardino City. Elected leaders in San Bernardino County took advantage of a window of opportunity by forging a new majority on the board that sought to change the decision dynamics by hiring a seasoned chief executive. To foster changes, sustained efforts are needed to involve stakeholders and build the process and stable expectations among stakeholders for reconciling their short- and long-term interests in budgeting decisions. But it remains to be seen whether such efforts can be maintained in the long run.

At the most general level, as argued by Ostrom, the key to resolving CPR dilemmas is to develop trust and reciprocity among participants. To operationalize this general argument, one must identify the impact of specific contexts on the formation or destruction of trust and reciprocity. Ostrom's micro-situational variables characterize a type of context that can facilitate the development of interactive dynamics supporting trust and reciprocity among participants. Table 1 summarizes how the three cases align with the six micro-situational variables. 
Communication Is Feasible with the Full Set of Participants

Los Angeles County has been able to develop and sustain a transparent budgetary process that facilitates open communication among department heads, the chief administrator/executive, and the board of supervisors. Budget discussions also include communications with stakeholders and networks of partnerships across the county. The case shows that communication with the public is important, but it needs to be structured in ways that facilitate thoughtful deliberation and analysis. In a large and politically diverse county like Los Angeles, it is important to not politicize every budgetary decision; freewheeling leaks to the press can be counterproductive. In San Bernardino City, there are few open communications between the city attorney and mayor/council. Even at the meeting declaring bankruptcy, the city attorney disagreed with council members on the city's fiscal condition. The broader community of stakeholders is seldom involved in budgetary communications. In San Bernardino County, efforts were made to enhance communications across departments and supervisory districts in the county and among relevant stakeholders in the entire region.

\section{Reputations of Participants Are Known}

Los Angeles County's reputation for conservative budgeting facilitates negotiation with unions regarding pension issues, as the unions can have confidence that short-term sacrifices by their members will be reliably compensated in the future. The known reputations reduce uncertainty and create incentives for considering long-term fiscal impacts, as well as for building trust. Good working relationships between the board and the chief administrator/executive also facilitate negotiation with the unions. Partnering organizations throughout the county know that sound fiscal decisions are consistently made, building trust among stakeholders throughout the county. In San Bernardino City, the reputations of long-standing participants actually worked against addressing the fiscal crisis. Reputations of key stakeholders are known, but only for the uncompromising stance they take in protecting their vested interests, as in the case of the public safety unions. In San Bernardino County, the new majority on the board has begun to demonstrate a commitment to developing an administrative structure and budgetary process that facilitates responsible budgetary decisions on behalf of the county as a whole, enhancing the members' reputations. The board chair and newly hired CEO had known reputations for responsible budgeting and strategic successes in their respective roles prior to taking their county positions.

\section{High Marginal Per Capita Return for Participants in Successful Collective Efforts}

In Los Angeles, supervisors are concerned about the political repercussions of major budgetary crises, but such concerns may not necessarily translate into concerted efforts unless other conditions for sustainable cooperation exist. The budgetary process and personnel policy link performance and efficiencies to budgetary allocation and rewards for employees in different departments. In San Bernardino City, the charter guarantees public safety officers' salaries and retirement benefits; as a result, they do not see any high return for cooperating with other stakeholders to address budgetary shortfalls. The absence of a robust civic infrastructure engaged with city government suggests the absence of a high rate of return for cooperation. In San Bernardino County, the new finance and budgeting system put in place by the new chief executive officer began to show department administrators that their departments would be rewarded for sound fiscal planning and decisions. The strategic planning process has begun to identify ways to partner with nonprofits and other governments to attain more efficient uses of resources.

\section{Entry or Exit Capabilities for Key Participants So That No One Can Be Taken for Granted}

In Los Angeles County, the professional expertise of staff, including the chief administrator, provides professional options beyond county employment. The exit option of key participants provides a level playing field in discussions between elected and appointed staff. In San Bernardino City, as a result of the deep divisions among elected leaders, appointed executives do not enjoy the security needed to lead credibly an orderly budgetary process. In San Bernardino County, the new chief executive officer has a strong professional reputation and was able to negotiate a five-year employment contract, which allowed him to carry out his reform agenda with long-term credibility.

\section{Longer Time Horizon}

In Los Angeles County, supervisors have usually had long tenure, including one serving for 40 years, but they are still subject to potential electoral challenges, especially if major budgetary crises emerge. A combination of long tenures and lessons learned from the Orange County bankruptcy created pressure for the supervisors to consider the long-term impact of annual budget decisions. An understanding emerged that if they sacrifice the long term to deal with short-time problems, they are likely to be the ones who have to deal with the consequences in years to come. Employees' belief in the long-term viability of the county's pension system encourages them to accept compromises to benefit cuts. In San Bernardino City, major elected officials were elected at different times and have different expectations about the duration of their tenure. The council members are subject to term limits. The long-serving city attorney is not subject to term limits and appeared to have a different agenda from those of other elected officials and administrators. There were no mechanisms in place for elected council members or city administrators to account for the long-term impact of negotiated labor agreements or annual budget decisions. In San Bernardino County, the 10-year expenditure forecast requirement has been built into the current budgetary process. It remains to be seen whether future supervisors and chief executives will continue to support the new budgetary process.

\section{Agreed-Upon Sanctioning Capabilities}

In Los Angeles County, internally, with the development of a system of integrated information flows, a strategic planning process involving all key departments, and a shared commitment to a long-term view, department heads face tangible sanctions (both formal and informal) for submitting inflated budgetary requests. Externally, by relying on the bond market and bond rating system for short-term borrowing (e.g., tax anticipation notes and revenue anticipation 
notes) and long-term borrowing, county supervisors face effective constraints on overextending fiscal resources. In addition, the statutory requirements for reporting created a regular transparency to the board, to professional staff, and to the bond market that served as sanctions against overappropriations. In San Bernardino City, mistrust between key elected officials makes it difficult for them to reach credible compromises and enforce them. Entrenched positions of the public safety unions also make it difficult to reach and enforce deals to maintain the city's long-term financial health. No effective community-based civic groups exist to hold city officials accountable for their fiscal mistakes. In San Bernardino County, the new budgetary process has become more transparent and involves participation from a wide variety of actors from both inside and outside the county government. Elected officials and department heads are now more likely to face both formal and informal sanctions for inflated budgetary requests.

This three-case comparison, by itself, cannot ascertain Ostrom's six micro-situational variables as either necessary or sufficient conditions for successful resolution of CPR dilemmas. Yet these six variables can serve as useful heuristics for identifying the relevant interactive dynamics among stakeholders in local fiscal governance situations, with Los Angeles illustrating a best-case scenario in contrast to the dismal situation in San Bernardino City, and the case of San Bernardino County illustrating possible strategies for reshaping interactive dynamics to avert potential fiscal disasters. Overall, the cases show that the interactive dynamics between elected officials and senior appointed staffs are always the key. They need not have identical interests, but their willingness to work with each other is a critical precondition for success. Reputable and professional chief executives play an important role in leading and maintaining a budgetary process that takes into account a broad range of interests in the entire community from a long-term perspective. To be successful, executives have to be empowered by the elected officials to present the jurisdiction's fiscal realities, both short and long term, regardless of political consequences. A transparent and forward-looking budgetary process is also essential for encouraging all stakeholders in the community to consider the long term when making fiscal decisions. For public administration professionals who are fortunate to be working in a jurisdiction in which all the favorable micro-situational conditions are in place, their main task would be to make sure that those conditions and arrangements are properly maintained. If not, the critical task is to identify what is lacking and what can be done to reframe the collective action dynamics among key stakeholders in the community.

Most important, this micro-situational perspective helps analysts and practitioners understand government fiscal decisions as more than simply static or internal budgetary control problems, but as dynamic processes requiring coordinated efforts among a multitude of actors in the local community and including at least elected representatives, appointed executives, career civil servants, union leaders, community leaders, and the public (Wang et al. 2012). The micro-situational perspective identifies that context matters, but that context is not immutable. Different actors all have their respective roles and sources of influence within the local jurisdiction; ultimately, they all need to be convinced to support fiscal decisions that may be disadvantageous for them in the short run but are beneficial to them and to the entire community in the long run. Interactive dynamics that foster trust and reciprocity are the foundation for successful collective action among these diverse actors in the community (Robertson and Tang 1995; Tang and Tang 2014).

In addition to the micro-situational variables, individuals coping with CPR dilemmas are also affected by a broader set of contextual variables related to the underlying institutional environments. After decades of research about the impact of institutional rules on CPR management, Ostrom came to the conclusion that specific rules associated with success or failure vary across different contexts, and it will be futile to try to pinpoint specific rules that are infallibly associated with successful cases (Ostrom 2010, 652). Instead, a more viable approach is to move up a level of generality by focusing on the broad "design principles" that may inform choices of institutional rules under diverse circumstances. Yet, as pointed out by Cox, Arnold, and Tomas (2010) and acknowledged by Ostrom, design principles may also risk being treated by practitioners as rigid blueprints for imposing uniform institutional rules on diverse settings. To counteract such possible misunderstandings, Ostrom proposes that "one can translate the design principles into a series of questions that could be asked when thinking about improving the sustainability of a common-pool resource system" (2005, 271). Thus, we examine next how the three cases may help answer Ostrom's questions on institutional design.

1. Well-defined boundaries. "How can we better define the boundaries of this resource, and of the individuals who are using it, so as to make clear who is authorized to harvest and where harvesting is authorized?" (Ostrom 2005, 271). A critical issue regarding the fiscal commons is not just who has a share of the revenue pool but also who has control (or entitlement) over which portion of it. In Los Angeles County, the board of supervisors, working with the chief executive, maintained control of the entire budget, allowing it the flexibility to make adjustments to expenditures according to projections on revenues and needs of the county.

The arrangement also enabled the board and the chief executive to negotiate credibly with different stakeholders in the county when making those adjustments. In San Bernardino City, the city charter guaranteed public safety officers automatic raises based on formulae that are incompatible with the local economic reality. These guaranteed entitlements created major difficulties, especially during economic downturns, for adjusting expenditures according to available revenue streams. San Bernardino County had a long tradition of allocating financial resources along district boundaries; this tradition created incentives for each supervisor to focus on protecting the fiscal share for his or her district while neglecting priority setting across districts. One strategy adopted to turn around the county's fiscal condition has been to break down this "silo" arrangement by giving the CEO's office greater authority in setting priorities across departments and geographic districts.

2. Proportional equivalence between benefits and costs. "How can we clarify the relationship between the benefits received and the 
contributions to the costs of sustaining this system?" (Ostrom 2005, 271). In sizable local jurisdictions, the fiscal commons is huge, involving billions of dollars in annual revenues and expenditures. In order to convince all stakeholders to contribute to sustaining the fiscal commons, credible information is needed to help stakeholders understand realistic revenue projections and competing priorities. Los Angeles County benefited from a transparent budgetary process that was based on a single point of coordination, consistent flow of information across departments, and the board of supervisors' regular involvement in considering relevant information and options. San Bernardino City, in contrast, showed a total absence of transparency and collaboration among key institutional actors in its budgetary process, epitomized by the July 2012 council meeting in which the city attorney and the mayor accused each other for not knowing the city's true financial condition. The turnaround effort in San Bernardino County was premised on developing an integrated financial tracking system across all departments, with a 10-year expenditure forecast in each budget presented to the board.

3. Collective choice arrangements. "How can we enhance the participation of those involved in making key decisions about this system?" (Ostrom 2005, 271). There are many potential stakeholders for the fiscal commons; a structured and orderly process is needed to aggregate inputs and consider options. In Los Angeles County, longserving supervisors had a long-term view about the county and were willing to work closely with the chief executive in making tough financial decisions on a regular basis. There was open communication among board members, the chief executive, and department heads; budgetary discussions regularly included communications with stakeholders and networks of partnerships across the county. In San Bernardino City, deep-rooted conflicts among the city attorney, mayor, and council members precluded open communication and orderly participation among key decision makers in the city. A largely disenfranchised electorate also failed to hold these key decision makers accountable for their fiscal mistakes. In San Bernardino County, part of the turnaround strategy included strategic planning processes involving county officials, city officials, civic leaders, and regional planning agency officials. Hired on a five-year employment contract and protected by a supermajority in the council, the new CEO was empowered to build on a broad-based strategic planning initiative and to develop a more structured way for department heads to participate in budgetary processes.

4. Monitoring. "Who is monitoring this system and do they face appropriate incentives given the challenge of monitoring?" (Ostrom $2005,271)$. In the context of California, where local self-governance is a valued tradition, the democratically elected council/board bears the ultimate responsibility for monitoring the fiscal commons within its jurisdiction. Members of the council/board do not have to share the same preferences and priorities, but they need to be willing to acquire fiscal fluency and to work with each other in upholding their fiduciary responsibilities. They are more likely to be willing to do so if they expect to serve the jurisdiction for the long term and the local electorate and other watchdog groups are active in holding the elected representatives accountable. To be an effective financial monitor, the council/board members need to be supported by professional managers who are willing to serve the council/board with integrity and without fear. These conditions are largely fulfilled in Los Angeles County but mostly missing in San Bernardino City, which was plagued by dysfunctional conflicts among elected officials. A new majority in the San Bernardino County board allowed for the hiring of a professional executive to take steps to correct past fiscal mistakes, but the long-term prospect for success hinges on whether future council members will continue to be motivated to work with each other to monitor the fiscal commons.

5. Graduated sanctions. "What are the sanctions we are authorizing and can they be adjusted so that someone who makes an error or a small rule infraction is sufficiently warned so as to ensure longer-term compliance without our trying to impose unrealistic sanctions?" (Ostrom 2005, 271). There are at least two related questions here. One concerns potential sanctions for elected officials making irresponsible fiscal decisions, and the other concerns discipline imposed on career officials. In Los Angeles County, supervisors usually had long tenure, but they were still subject to potential electoral challenges. Because the county also had a large portfolio of bond issues, financial missteps could easily trigger punitive actions by the financial market. County supervisors were well aware of the long-term headache they had to suffer by making fiscal mistakes. Being empowered by the board, the chief executive was able to develop and sustain a budgetary process in which department heads faced tangible sanctions (both formal and informal) for submitting inflated budgetary requests. In San Bernardino City, mistrust among entrenched elected officials made it difficult for them to reach credible compromises and enforce them. There were no strong electorate and civic community to hold the elected officials accountable for their financial mistakes. With their financial interests protected by the charter, public safety officials faced little risk in resisting demands for financial concessions. In San Bernardino County, there have been known corrupt practices among elected and nonelected officials, indicating lapses in the county's political accountability system. Yet a new majority of the board provided the impetus for hiring a new chief executive who tried to put in place a budgetary process that sanctioned against inflated budgetary requests from both elected officials and department heads.

6. Conflict-resolution mechanisms. "What local and regional mechanisms exist to resolve conflicts arising over the use of this resource?" (Ostrom 2005, 271). In a local jurisdiction, the elected council/board is ultimately the arena in which conflicts over the fiscal commons are resolved. In this regard, an open, deliberative, and accountable council/board is important. But many financial conflicts cannot be resolved simply by a majority vote in the council/ board. For example, whether employee unions are willing to accept cutbacks to their salaries and benefits often depends on whether the elected officials and chief executives are known to have good working relationships and whether they can be trusted to conduct goodfaith negotiations and to keep promises made in those negotiations. Apparently, these kinds of conflict resolution mechanisms were well in place in Los Angeles City but not in San Bernardino City, while San Bernardino County was in the process of strengthening such mechanisms.

7. Minimal recognition of rights. "Are there functional or creative efforts by local appropriators to craft effective stewardship mechanisms for local resources that should be recognized?" (Ostrom 2005, 271). As mentioned earlier, the state of California has a long tradition of supporting self-governance of local jurisdictions. At least for 
the three jurisdictions covered in this study, state recognition of rights for crafting stewardship mechanisms for the local fiscal commons appears to be well established. In recent years, however, there have been attempts by the state government to implement statewide policy reform, such as the elimination of local redevelopment agencies, which may have long-term negative fiscal impacts on local jurisdictions. These issues are beyond the scope of this article, but one may note that it is not necessarily a lack of recognition of rights but actions by higher-level governments that may create additional stresses on the local fiscal commons and would test local jurisdictions' capacity for handling them.

8. Nested enterprise. "How can we create a multi-layer, polycentric system that can be dynamic, adaptive, and effective over time?" (Ostrom 2005, 271). In governing the local fiscal commons, the budgetary process is the focal point for collaboration among stakeholders. Yet as illustrated in the three cases, the budgetary system does not operate in isolation. To be an effective tool for fiscal sustainability, the budgetary process must be nested within a political environment in which elected officials, nonelected officials, civic leaders, and the electorate all contribute to supporting transparency, accountability, and collaboration.

Seen from the findings corresponding to these eight questions, it is apparent that none of the three usual factors discussed in the public finance literature-ex ante fiscal rules, electoral rules, the budget process_-can fully explain by itself the conditions for fiscal sustainability. Many endogenous factors are in play. For example, a city charter in San Bernardino City that guarantees salary raises for public safety employees does not make sense from the perspective of responsible budgeting, but the adoption of such a charter provision reflects the city's underlying politics. Fiscal sustainability is ultimately premised on local political processes that encourage stakeholders to look beyond their immediate self-interests and to support fiscal decisions that protect their own long-term interests as well as the long-term well-being of the community.

Sound design principles for defining fiscal decision rights, information availability, monitoring, sanctioning, collective choice, and conflict resolution mechanisms can guide the development of appropriate institutional arrangements, both formal and informal, that fit the particular circumstances of a local jurisdiction. A wellcoordinated budgetary process is essential for avoiding commons dilemmas in fiscal decision making. Yet such a budgetary process is not viable unless it is supported by other related transactions in the community that reinforce mutual expectations for trust and reciprocity among all the key stakeholders. As shown in our analysis, it is important that the elected council maintains control of the entire budget and empowers professional managers to negotiate credibly with different stakeholders; credible information with realistic revenue and expenditure projections is made available to all stakeholders; there is a transparent budgetary process with a coordinated and consistent flow of information across departments and stakeholder groups; and established mechanisms exist to sanction elected officials and professional managers for making fiscal mistakes. A key to fiscal sustainability is to draw on sound design principles (but not rigid blueprints) to develop a set of self-enforcing institutions and organizational practices in which participants are motivated to help support the same rules that constrain their claims on the common revenue pool, with an understanding that doing so will be in their long-term interest (Greif 2006; Tang 2012).

\section{Conclusion}

By viewing local government fiscal sustainability as a CPR problem, this article has examined a set of micro-situational variables that explain the success or failure of participants in developing the trust and reciprocity needed to overcome the social dilemmas inherent in many fiscal and budgetary decisions. Our analysis shows that the six micro-situational variables can serve as useful heuristics for analyzing how different interactive dynamics may lead to successful or failure in managing the local fiscal commons. The analysis also shows the importance of seeing local fiscal decisions not just as internal budgetary control issues but also as collective action problems among a diverse set of stakeholders. Institutional designs that facilitate transparency, coordinated efforts, accountability, and conflict resolution among diverse stakeholders are key to resolving fiscal commons dilemmas.

This article contributes to the CPR literature by showing a new approach to in-depth case comparison that links two sets of context-micro-situational variables and design principles-into a consolidated diagnostic analysis (Cox, Arnold, and Tomas 2010; Young 2002). The article can also be seen as a first step toward developing a comprehensive research agenda for studying fiscal sustainability issues from a CPR perspective. Chapman (2008), for example, outlines a number of possible revenue, expenditure, and administrative "solutions" to fiscal sustainability challenges faced by state and local governments. Logical next steps in Chapman's analysis would be to define more precisely the different types of CPR problems related to these revenue, expenditure, and administrative "solutions," to develop a more systematic method of identifying cases that face similar types of CPR problems, and to examine how variations in context affect the relevant microsituational variables. In addition, the tension of the electorate (Korey 2011), with higher expectations for services (i.e., increased demand) while simultaneously wanting reduced property, sales, and other taxes (i.e., decreased supply), needs to be researched in the context of the CPR framework. The best practices identified in these and related cases (Pisano and Callahan 2013a) need to be tested within the CPR framework across a wide range of jurisdictions.

Fiscal sustainability will remain an ongoing topic, with the projected "fiscal gap" faced by local jurisdictions continuing to widen in the coming decades (GAO 2013; Goldberg and Neiman 2014; Pisano 2013). Closing the gap will require some combination of expenditure reduction, revenue increase, and, more important, modifications of 
institutional design informed by research. The example in the CPR literature of a groundwater basin facing the prospect of ruin because of overpumping or insufficient replenishment (Blomquist 1992) provides a cautionary metaphor for understanding the dynamics leading to depletion of fiscal resources. Understanding the collective action challenges inherent in CPR governance will be a key to attaining fiscal sustainability in the coming decades.

\section{Acknowledgments}

Research for this article was supported by generous grants for three years from the John Randolph Haynes and Dora Haynes Foundation. We gratefully acknowledge the partnership with our colleagues at the National Civic League-Gloria Rubio-Cortes, Michael McGrath, and Sarah Lipscomb-in conducting the case research and preparing this article. We thank many scholars and practitioners who commented on previous drafts of this article in writing and during expert panel discussions. We also thank the editors and anonymous reviewers for their valuable comments and suggestions.

\section{Note}

1. See also Ostrom $(2010,653)$ for a slightly modified list.

\section{References}

Baqir, Reza. 2002. Districting and Government Overspending. Journal of Political Economy 110(6): 1318-54.

Bifulco, Robert, Beverly Buch, William Duncombe, Mark Robbins, and William Simonsen. 2012. Debt and Deception: How States Avoid Making Hard Fiscal Decisions. Public Administration Review 72(5): 659-67.

Blomquist, William A. 1992. Dividing the Waters: Governing Groundwater in Southern California. Oakland, CA: ICS Press.

Blomquist, William A., Edella Schlager, and Tanya Heikkila. 2004. Common Waters, Diverging Streams: Linking Institutions and Water Management in Arizona, California, and Colorado. Washington, DC: Resources for the Future.

Callahan, Richard F. 2007. Governance: The Collision of Politics and Cooperation. Public Administration Review 67(2): 299-301.

Callahan, Richard F., and Mark Pisano. 2014. Bankruptcy: The Divergent Cases of the City and the County of San Bernardino. Public Finance and Management 14(1): 84-105.

Chapman, Jeffrey I. 2008. State and Local Fiscal Sustainability: The Challenges. Special issue, Public Administration Review 68: S115-31.

Cox, Michael, Gwen Arnold, and Sergio Villamayor Tomás. 2010. A Review of Design Principles for Community-Based Natural Resource Management. Ecology and Society 15(4): 1-19 (special section).

Feiock, Richard C. 2013. The Institutional Collective Action Framework. Policy Studies Journal 41(3): 397-425.

Feiock, Richard C., and John T. Scholz, eds. 2010. Self-Organizing Federalism: Collaborative Mechanisms to Mitigate Institutional Collective Action Dilemmas. New York: Cambridge University Press.

Gardner, J. W. 1996. Building Community. Washington, DC: Independent Sector Leadership Studies Program.

Goldberg, Jeremy M., and Max Neiman. 2014. Managing Budgets during Fiscal Stress: Lessons for Local Government Officials. Washington, DC: IBM Center for the Business of Government.

Greif, Avner. 2006. Institutions and the Path to the Modern Economy: Lessons from Medieval Trade. New York: Cambridge University Press.

Heinrich, Carolyn J., Carolyn J. Hill, and Laurence E. Lynn, Jr. 2004. Governance as an Organizing Theme for Empirical Research. In The Art of Governance: Analyzing Management and Administration, edited by Patricia W.
Ingraham and Laurence E. Lynn, Jr., 3-19. Washington, DC: Georgetown University Press.

Knight, Jack, and James Johnson. 2011. The Priority of Democracy: Political Consequences of Pragmatism. Princeton, NJ: Princeton University Press.

Korey, John L. 2011. California: Failed State or Too Big to Fail? California Journal of Politics and Policy 3(2): 1-21.

Lam, Wai Fung. 1998. Governing Irrigation Systems in Nepal: Institutions, Infrastructure, and Collective Action. Oakland, CA: ICS Press.

Ostrom, Elinor. 1990. Governing the Commons: The Evolution of Institutions for Collective Action. New York: Cambridge University Press.

- 2005. Understanding Institutional Diversity. Princeton, NJ: Princeton University Press.

2006. Converting Threats into Opportunities. PS: Political Science and Politics 39(1): 3-12.

- 2009. A General Framework for Analyzing Sustainability of SocioEcological Systems. Science 325: 419-22.

- 2010. Beyond Markets and States: Polycentric Governance of Complex Economic Systems. American Economic Review 100(3): 641-72.

Ostrom, Elinor, Roy Gardner, and James Walker. 1994. Rules, Games, and Common-Pool Resources. Ann Arbor: University of Michigan Press.

Peterson, Paul E. 1995. The Price of Federalism. Washington, DC: Brookings Institution Press.

Pisano, Mark. 2013. Demography Is Economic Destiny. America 2050, December. http://www.america2050.0rg/Pisano-Demography.pdf [accessed August 18, 2014].

Pisano, Mark, and Richard F. Callahan. 2012. Los Angeles County Fiscal Sustainability. National Civic Review 101(1): 11-17.

. 2013a. County of San Bernardino Case Study. National Civic Review 102(1): 3-6.

_ 2013b. Developing Effective Mechanisms that Promote Fiscal Sustainability. Government Finance Review, October, 74-77.

Raadschelders, Jos C. N. 2011. Public Administration: The Interdisciplinary Study of Government. New York: Oxford University Press.

Robertson, Peter J., and Shui-Yan Tang. 1995. The Role of Commitment in Collective Action: Comparing the Organizational Behavior and Rational Choice Perspectives. Public Administration Review 55(1): 67-80.

Schlager, Edella, and Tanya Heikkila. 2011. Left High and Dry? Climate Change, Common-Pool Resource Theory, and the Adaptability of Western Water Compacts. Public Administration Review 71(3): 57-60.

Shanforth, Frank, and Mike Lawson. 2013. A "Perfect Storm" in San Bernardino County. Report, George Mason University Center for State and Local Government Leadership. http://s3.amazonaws.com/chssweb/documents/12789/ original/GMU_San_Bernardino_9.13.pdf?1379560583 [accessed August 18, 2014].

Tang, Ching-Ping, and Shui-Yan Tang. 2001. Negotiated Autonomy: Transforming Self-Governing Institutions for Local Common-Pool Resources in Two Tribal Villages in Taiwan. Human Ecology 29(1): 49-67.

- 2014. Managing Incentive Dynamics for Collaborative Governance in Land and Ecological Conservation. Public Administration Review 74(2): 220-31.

Tang, Shui-Yan. 1991. Institutional Arrangements and the Management of Common-Pool Resources. Public Administration Review 51(1): 42-51. - 1992. Institutions and Collective Action: Self-Governance in Irrigation. Oakland, CA: ICS Press. - 2012. Ten Principles for a Rule-Ordered Society: Enhancing China's Governing Capacity. Beijing, China: Economic Publishing House.

U.S. Government Accountability Office (GAO). 2013. State and Local Governments' Fiscal Outlook: April 2013 Update. http://www.gao.gov/ assets/660/654255.pdf [accessed August 18, 2014]. 
Von Hagen, Jürgen. 2006. Political Economy of Fiscal Institutions. In The Oxford Handbook of Political Economy, edited by Barry R. Weingast and Donald A. Wittman, 464-78. Oxford, UK: Oxford University Press.

Walters, D. 2012. Bankruptcy May Rein in Pensions. Sacramento Bee, November 5. Wang, XiaoHu, Christopher V. Hawkins, Nick Lebredo, and Evan M. Berman. 2012. Capacity to Sustain Sustainability: A Study of U.S. Cities. Public Administration Review 72(6): 841-52.
Weingast, Barry R., Kenneth A. Shepsle, and Christopher Johnsen. 1981.

The Political Economy of Benefits and Costs: A Neoclassical Approach to Distributive Politics. Journal of Political Economy 89(4): 642-64.

Yin, Robert K. 1994. Case Study Research: Designs and Methods. 2nd ed. Thousand Oaks, CA: Sage Publications.

Young, Oran R. 2002. The Institutional Dimensions of Environmental Change: Fit, Interplay, and Scale. Cambridge, MA: MIT Press.

If you are interested in submitting a manuscript to

\section{Public Administration Review,}

please review the guidelines under publications at www.aspanet.org and follow the submission instructions. 